\title{
Ten questions concerning future buildings beyond zero energy and carbon neutrality
}

Na Wang*a Patrick E. Phelan ${ }^{\mathrm{b}}$, Jorge Gonzalez ${ }^{\mathrm{c}}$, Chioke Harris ${ }^{\mathrm{d}}$, Gregor Henze $^{\mathrm{e}}$, Robert Hutchinson ${ }^{\mathrm{f}}$, Jared Langevin ${ }^{\mathrm{g}}$, Mary Ann Lazarus ${ }^{\mathrm{h}}$, Brent Nelson ${ }^{\mathrm{i}}$, Chris Pyke ${ }^{\mathrm{j}}$, Kurt Roth $^{\mathrm{k}}$, David Rouse ${ }^{\mathrm{l}}$, Karma Sawyer ${ }^{\mathrm{m}}$, Steve Selkowitz ${ }^{\mathrm{n}}$

${ }^{a}$ Pacific Northwest National Laboratory, 902 Battelle Boulevard; P.O. Box 999, Richland, WA 99352 USA

*Corresponding author. Telephone: (571) 830-6536

Email address: na.wang@pnnl.gov

${ }^{\mathrm{b}}$ Arizona State University, School for Engineering of Matter, Transport \& Energy; 501 E Tyler Mall, ECG 303, Tempe, AZ 85287 USA

Email addresses: phelan@asu.edu

${ }^{c}$ City University of New York, Grove School of Engineering, 160 Convent Avenue, New York, NY 10031

USA

Email address: gonzalez@me.ccny.cuny.edu

${ }^{d}$ (None)

Email addresses: chioke.harris@gmail.com

${ }^{\mathrm{e}}$ University of Colorado, Department of Civil, Environmental and Architectural Engineering, Boulder, CO 80309 USA

Email address:gregor.henze@colorado.edu

${ }^{f}$ Rocky Mountain Institute, 1820 Folsom, Boulder CO 80302 USA

Email address: hhutchinson@rmi.org

${ }^{g}$ Lawrence Berkeley National Laboratory, 1 Cyclotron Rd, Berkeley, CA 94720 USA

Email:jared.langevin@lbl.gov

${ }^{h}$ MALeco, LLC, 4388 McPherson Ave, Saint Louis, MO 63108 USA

Email address: mary.ann.lazarus@gmail.com 
${ }^{i}$ Northern Arizona University, Department of Mechanical Engineering, PO Box 15600, Flagstaff, AZ 86011 USA

Email address: brent.nelson@nau.edu

${ }^{j}$ Aclima, Inc., 10 Lombard Street, San Francisco, CA 94111 USA

Email address: chris.pyke@aclima.io

${ }^{k}$ Fraunhofer Center for Sustainable Energy Systems CSE, 5 Channel Center Street, Boston, MA 02210 USA

Email address:kroth@cse.fraunhofer.org

${ }^{l}$ American Planning Association, 1030 15th Street, NW, Suite 750 West, Washington, DC 20005 USA

Email address:drouse@planning.org

m (None)

Email address: karma.sawyer@gmail.com

${ }^{n}$ Lawrence Berkeley National laboratory, 1 Cyclotron Rd, Berkeley, CA 94720

Email address: seselkowitz@lbl.gov 


\begin{abstract}
Architects and planners have been at the forefront of envisioning a future built environment for millennia. However, fragmental views that emphasize one facet of the built environment, such as energy, environment, or groundbreaking technologies, often do not achieve expected outcomes. Buildings are responsible for approximately one-third of worldwide carbon emissions and account for about $40 \%$ of primary energy consumption in the U.S. In addition to achieving the very ambitious goal of reducing building-associated greenhouse gas emissions by $75 \%$ by 2050 , buildings must improve their functionality and performance to meet current and future human, societal, and environmental needs in a changing world. In this article, we introduce a new framework to guide potential evolution of the building stock in the next century, based on greenhouse gas emissions as the common thread to investigate the potential implications of new design paradigms, innovative operational strategies, and disruptive technologies. This framework emphasizes integration of multidisciplinary knowledge, scalability for mainstream buildings, and proactive approaches considering constraints and unknowns. The framework integrates the interrelated aspects of the built environment through a series of quantitative metrics that aim to improve environmental outcomes while optimizing building performance to achieve healthy, adaptive, and productive buildings.
\end{abstract}

Keywords: vision; energy; greenhouse gas emission; technologies; sustainability; resilience. 


\section{Introduction}

Buildings are responsible for approximately one-third of global primary energy consumption and onethird of total direct and indirect energy-related greenhouse gas (GHG) emissions [1]. The ambitious goal of reducing building GHG emissions by $75 \%$ by 2050 [2] remains challenging because fragmented solutions that emphasize only a single driving factor, such as innovative energy systems [3], control of climate tipping points [4], or water resource engineering [5], may fall short of the desired outcomes that minimize environmental impacts while achieving healthy, adaptive, resilient, and productive buildings.

Buildings are a challenge and an opportunity for environmental sustainability. On one hand, population and economic growth and urbanization [6], with the increasing demand for energy, land, water, and other resources, are causing major economic and environmental transformations. Buildings are a reflection of this growth and are where humans spend over $90 \%$ of their time [7], directly contributing to many energy and environmental issues. Buildings use significant volumes of water for direct consumption and power generation and affect long-term water availability by contributing to storm water runoff and climate change [8]. The GHG emissions, landfill waste, and pollution $\left(\mathrm{SO}_{2}\right.$, airborne particulates) produced from building construction and operation are directly related to health threats [9]. On the other hand, urban living promotes energy efficiency from dense buildings and reduced land use [10], with the addition that a well-designed, positive indoor environment can significantly increase occupant satisfaction, health, and productivity [11].

Aggregate building development at the district and city scales and beyond has profound effects on environmental and human health and well-being. One critical outcome of urban building development since World War II has been sprawl—characterized by unplanned and uneven patterns of growth, driven by processes such as the advent of personal vehicles, market demands, and public infrastructure investments, and leading to inefficient resource use [12].

What should be the long-term vision for our total built environment? Past visions for buildings that draft solutions based on a clean slate (such as Bruno Taut's Utopian City in 1919 [13], Le Corbusier's 
Radiant City in 1924 [14], Frank Lloyd Wright's Broadacre City in 1932 [15], and Paolo Soleri's Arcosanti in 1970 [16]) proved difficult to realize. Current benchmark frameworks for sustainable buildings are focused on driving near-term market transformation or describing specific sets of goals for exemplary performance [17]-[19]. An integrated vision that is concerned with the long-term evolution of the U.S. building stock is needed that moves the full breadth of buildings from exemplary to "typical" performers. Furthermore, this vision acknowledges that the individual buildings of the future will connect to community systems and resources such as transportation, utility infrastructure, and land use. Emerging $21^{\text {st }}$ Century challenges, such as vulnerability to a changing climate and the need for a more resilient built environment, are historical opportunities to develop a forward-looking vision of future buildings.

\subsection{Building stock turnover}

According to the International Energy Agency [1], more than half of the current global building stock will still be standing in 2050; in OECD (Organisation for Economic Co-operation and Development) countries (where buildings are more frequently refurbished than replaced), perhaps three-quarters of existing buildings will still be in use. Assuming an 80-year average life of buildings in the U.S. [20], Figure 1 shows one scenario of the U.S. building stock turnover in the next 100 years. (Note that the median expected lifetime for nonresidential buildings in the U.S. ranges from 50 to 65 years, depending on the use type.) Building evolution is a relatively slow but continuous process. A third to a half of the building stock is always over 40 years old and needs major renovations. Retrofitting the existing stock of buildings is an ongoing effort, which applies not only to existing buildings, but also to those in the future-i.e., buildings that are being built and will be built in the next decades.

With sustainable development calling for even longer building service life, the challenge is to keep up with the fast-changing technologies and consumer preferences in the future. This requires innovative ways to rethink how buildings can be designed and constructed. Acknowledging the gradual but dynamic building stock turnover process that will occur over the next century, we envision common building 
characteristics that will apply to retrofits of existing buildings as well as to new construction. A vision described for buildings 100 years from today may take 100 years to realize.
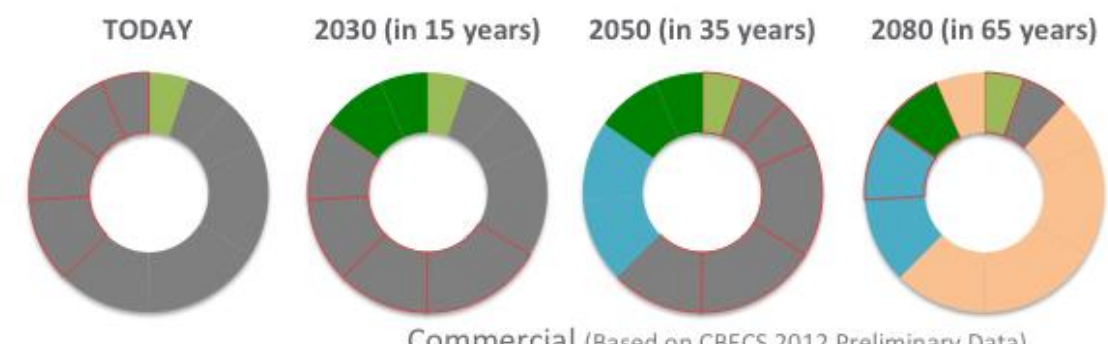

2115 (in 100 years)

Commercial (Based on CBECS 2012 Preliminary Data)
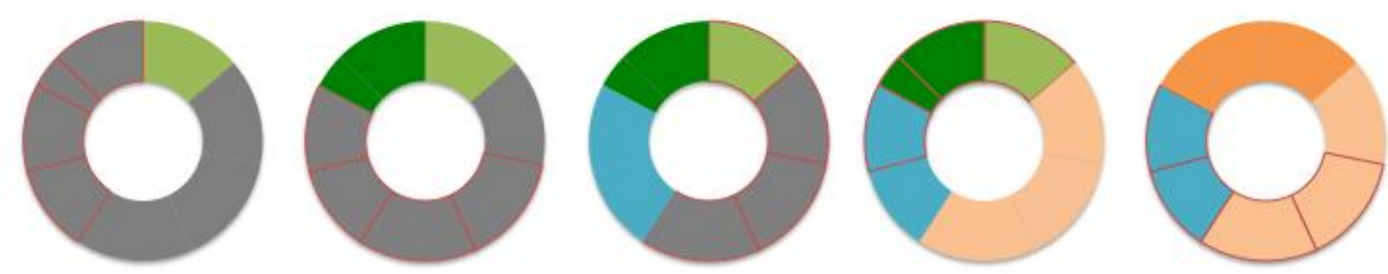

Residential (Based on RBCS 2009 Data)

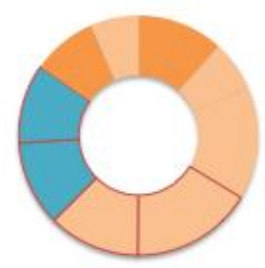

Today's average building

High efficiency building ( $<10$ years old today)

New constructions and major renovations towards "Net Zero"

New constructions and major renovations towards "Carbon Neutral"

"Future" new constructions and major renovations after 2050

"Future" new constructions and major renovations after 2080

Buildings over 40 years old

Note: Assumes 80 years of average service life; NOT including added building volume.

Figure 1. One scenario of building stock turnover in the U.S.

\subsection{Approach to developing a 100-year vision}

We conducted a year-long research effort through panel discussions and structured workshops that involved collaboration among hundreds of thought leaders in various fields related to building development. The topics included resilience, biomimicry and biophilia, smart cities and urban informatics, building-grid integration, building codes and regulations, public health, occupant behavior, enabling technologies and building controls, information technologies and Internet of Things, building envelope technologies and additive manufacturing, real estate market dynamics, and security [21]. A special issue of the ASME Journal of Solar Energy Engineering includes a number of articles that address some of these aspects in more detail [22]. 
Acknowledging the unpredictability of the future, we consider the common context under all future scenarios to include changing demography, demand for affordable housing and livable environments, and continuing pursuit of health and wellbeing. Aging population, due to rising life expectancy and declining birth rates [23]-[24], poses more challenges to building development, which needs to accommodate the physical and social needs of the growing senior population. Buildings in urban areas will remain the focus of discussion as population growth and urbanization continue throughout the century [23], [25]-[26]. The pursuit of built environments that support health and wellbeing is considered as the major driver of building and city developments. During our panel discussions, we asked participants what the most important attributes of future buildings would be. Increasing health, productivity, and wellbeing was rated as the most important building characteristic among the nearly 600 respondents, regardless of their background.

Based on the above projections, we explored a new framework to guide the evolutionary design process of the U.S. building stock. The framework includes desired characteristics of future buildings that are derived from multidisciplinary perspectives (i.e., environmental science, climatology, transportation, urban planning, public health, building and urban science). We use energy and GHG emissions as the common thread to examine interrelated aspects of the built environment and investigate the potential implications of supporting design paradigms, strategies, and technologies that could change the built environment. After developing descriptive building characteristics, we developed corresponding quantitative metrics, as well as average nationwide 100-year targets. Through the following 10 questions, we discuss 14 metrics for measuring future building performance. Many of these metrics use GHG emissions as a common measurement to cross-compare various aspects of buildings. These proposed metrics and associated 100-year targets directly tie building functions, occupants, and economics to buildings' environmental impact. 


\section{A 100-year vision: key characteristics of future buildings}

The framework consists of a systematic list of future building characteristics in five categories

(Figure 2). These characteristics link a number of key measures of building performance, such as energy and water use, GHG emissions, waste, material consumption, environmental resiliency, and occupant health and productivity. The characteristics also incorporate many actors and infrastructure systems (e.g., utility infrastructure, building controls and communications, real estate market dynamics, construction and procurement, regulatory reforms, occupant needs, environmental concerns, urban transportation) that influence the way buildings are designed and operated. These characteristics are closely interrelated. The ultimate goal of achieving a sustainable, resilient, efficient, and healthy built environment cannot be achieved by only focusing on one aspect.

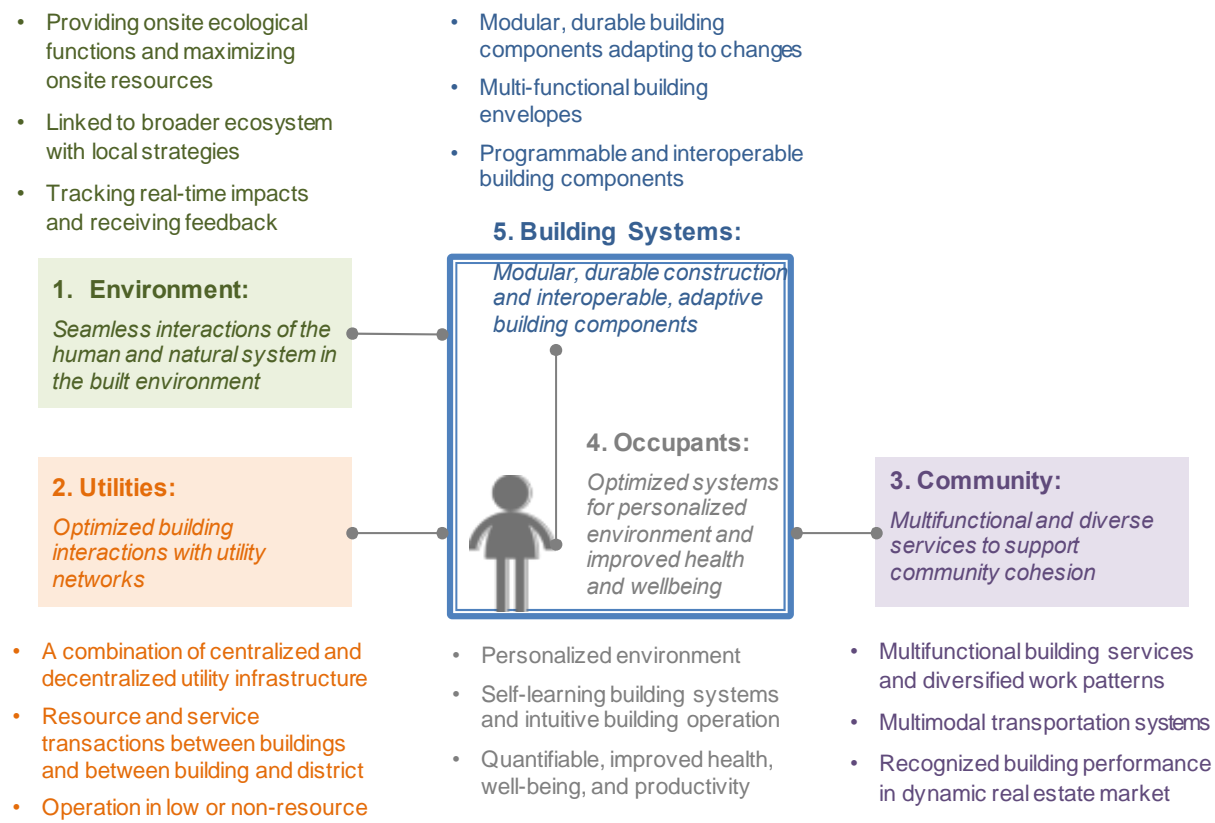

- Personalized environment

- Self-learning building systems and intuitive building operation

- Quantifiable, improved health, well-being, and productivity

Multifunctional and diverse

services to support

community cohesion

- Multifunctional building services and diversified work patterns

- Multimodal transportation systems

- Recognized building performance in dynamic real estate market

Figure 2. Five key characteristics of buildings of the future 


\subsection{Environment: seamless interactions of the human and natural systems in the built environment}

While allowing for improvement in occupant comfort despite fluctuations in regional climates, buildings will harvest environmental resources available on site for heating, cooling, lighting, and electricity, before using mechanical and infrastructure sources. Design solutions will be developed (but not limited) based on natural systems' strategies and functionalities such as biomimicry [27]. Buildings will be tied to the broader cycle of the region, including water cycles, the nutrient load, manufacturing impact, and factors that affect our health. Natural processes will be integrated into the built environment through green infrastructure [28], and the built environment will emphasize a close connection between humans and nature, such as biophilic design [29], to promote health and wellness. Buildings will constantly sense and control their impact by measuring outflows (water, heat, airflow) and monitoring their contribution to the aggregated impact on the micro- and macro-environments. A reduction of the urban heat island effect will be a key environmental performance indicator [30].

\subsection{Utilities: optimized building interactions with utility networks}

Future buildings will rely on common critical infrastructure (power, water, waste) via a combination of centralized and decentralized networks for generation, distribution, storage, and treatment. Buildings will be connected to their neighbors to share or trade building services and utility resources, including energy generation and storage, demand flexibility, waste heat recovery, water purification, onsite waste treatment, and localized air-cleaning, among others. Buildings will be able to adapt to and operate in lowor non-resource situations. Adaptive buildings will prepare for extreme environmental conditions, taking advantage of low-tech and distributed solutions, and rely on local resources to operate during catastrophic events. 


\subsection{Community: multifunctional and diverse services to support community cohesion}

Buildings will become more multifunctional, and occupant expectations for buildings will go beyond basic needs such as thermal comfort. Buildings will accommodate the needs of a changing demography (such as aging population [24]) and provide services to enhance work-life balance. Buildings will be connected by a multimodal transportation network integrating established modes such as walking and biking with new technologies such as autonomous vehicles. A more efficient transportation network will significantly reduce land use demand for automobile circulation and parking, making more space available for pedestrians and green space that performs onsite ecological functions [31]. Buildings' holistic performance, including embodied energy, impact on health, and life cycle assessment, will be measured, tracked, and recognized.

\subsection{Occupants: optimized systems for personalized environment and improved health and wellbeing}

Future building designs may turn to more personalized thermal comfort provision through portable or wearable devices that reduce the need for space heating and cooling while maintaining air quality [32][33]. Central systems and local devices will work together to deliver personalized levels of service to each occupant. Buildings will learn occupant behavior and expectations from experience to tailor building energy and resource consumption to actual needs [34]. Building-wide or city-wide intelligent applications will collaborate and exchange data to optimize outcomes. Buildings will be seen as a mechanism that helps generate a healthy life. The aggregated health benefits will be quantified via biometric data of building occupants while preserving personal privacy. 


\subsection{Building systems: modular, durable construction and interoperable, adaptive building components}

Buildings will consist of modular systems that are easy to reconfigure and upgrade to accommodate various needs and adapt to function or condition (weather, environment) changes over time. The design and manufacturing process will be well integrated to ensure plug and play. Building envelopes will embrace responsive and dynamic materials to provide more complex functions such as generating energy, collecting water, controlling light, regulating indoor temperature, or filtering air. Occupant lighting, thermal, and ventilation needs that cannot be met by these smart, adaptive systems will be supplied by highly efficient, integrated building systems. Building components will support easy interconnection, update, and extensibility.

\section{Ten questions concerning key metrics and targets for future buildings}

For each category of building characteristic, we identified two or three quantitative performance metrics associated with long-term targets (Table 1). It would be difficult to promote fundamental changes in the current building practice without defining targets for what we propose to achieve. The metrics are intended to take the first step towards transferring the vision into actions. With technological advances, there is no doubt that there would be various means to achieve the targets. As we previously discussed, building stock evolution is a lengthy process, and the metrics and targets not only set the end goals, but also show the path on which interval milestones are needed before we can realize the vision.

One challenge in identifying metrics for buildings 100 years in the future is that we are limited by our current technology, data collection, and ways of thinking. We focus on the metrics that are measurable with foreseen technology developments, if not with today's technology, unbiased by current problems, adaptable to building evolution, and applicable to mainstream buildings. Some proposed metrics may not be feasible with current practices due to economic and policy barriers, but we expect that these barriers will be overcome with time and technological advances. These metrics are interconnected to form a 
unified, comprehensive building performance evaluation. The group of metrics should be considered as a whole, not as individual targets. This is essential to realize a holistic vision for future buildings. 
Table 1. Summary of building characteristics, performance metrics, and targets.

Note: All metrics refer to annualized values when not specified otherwise. Most metrics are applicable to individual buildings (commercial and residential). The 100-year targets are defined for national averages.

\begin{tabular}{|c|c|c|c|c|c|}
\hline & Building Characteristics & No. & Metrics & 100-year Nationwide Targets & Baseline \\
\hline \multirow{3}{*}{ 竞 } & \multirow{3}{*}{$\begin{array}{l}\text { Seamless interactions of the human and natural system } \\
\text { in the built environment } \\
\text { - Providing onsite ecological functions and maximizing } \\
\text { onsite resources } \\
\text { - Linked to broader ecosystem with local strategies } \\
\text { - Tracking real-time impacts and receiving feedback }\end{array}$} & 1 & $\begin{array}{l}\text { Biodiversity (measured at building site using 0-1 } \\
\text { Simpson Index of Biodiversity) }\end{array}$ & $\begin{array}{l}\text { For new construction, predevelopment level } \\
\text { just prior to building construction; for } \\
\text { retrofit, maintain or exceed pre-renovation } \\
\text { level }\end{array}$ & Depending on the inhabited biotopes and regional climate \\
\hline & & 2 & $\begin{array}{l}\text { Imported daily water consumption per person } \\
\text { (liters/person) in buildings }\end{array}$ & $20 \%$ of today's level & 518 liters (137 gallons) per person (2010) \\
\hline & & 3 & $\begin{array}{l}\text { Percentage of all U.S. buildings tracking energy and } \\
\text { water consumption, GHG emissions (including } \\
\text { buildings and occupant commutes), indicators of } \\
\text { indoor and outdoor air quality, and impact on } \\
\text { microenvironment in real time }\end{array}$ & $\begin{array}{l}100 \% \text { of U.S. commercial and residential } \\
\text { buildings }\end{array}$ & $\begin{array}{l}64.7 \text { million advanced metering infrastructure installations } \\
\text { in the U.S., } 88 \% \text { for residential buildings, covering } 43 \% \text { of } \\
\text { homes ( } 2015 \text { ) } \\
43 \% \text { commercial floor space with HVAC BAS and } 14 \% \\
\text { with lighting BAS (2012) }\end{array}$ \\
\hline \multirow{3}{*}{ 总 } & \multirow{3}{*}{$\begin{array}{l}\text { Optimized building interactions with utility networks } \\
\text { - A combination of centralized and decentralized utility } \\
\text { infrastructure } \\
\text { - Resource and service transactions between buildings and } \\
\text { between building and district } \\
\text { - Operation in low- or non-resource situations }\end{array}$} & 4 & $\begin{array}{l}\text { Average operating GHG emissions per floor area } \\
\left(\text { metric tons } / \mathrm{m}^{2}\right)\end{array}$ & Zero & $\begin{array}{l}0.072 \text { metric ton } / \mathrm{m}^{2}(2015) \\
\left(0.007 \text { metric ton } / \mathrm{ft}^{2}\right)\end{array}$ \\
\hline & & 5 & $\begin{array}{l}\text { Capacity to reduce peak load, and to transact the } \\
\text { remaining peak load }\end{array}$ & $\begin{array}{l}\text { Reduce peak load by } 50 \% \text {, and transact } \\
50 \% \text { of the remaining peak load }\end{array}$ & $\begin{array}{l}\text { Nationwide peak summer demand in buildings is } \\
29.7 \mathrm{~W} / \mathrm{m}^{2}(2013)\end{array}$ \\
\hline & & 6 & $\begin{array}{l}\text { Percentage of loads within a micro-grid that can } \\
\text { operate without external energy supply within a time } \\
\text { period }\end{array}$ & $\begin{array}{l}100 \% \text { critical loads can operate at full } \\
\text { function for at least } 1 \text { week; } 50 \% \\
\text { noncritical loads can operate at reduced } \\
\text { function for } 48 \text { hours (or } 25 \% \text { for one } \\
\text { week) }\end{array}$ & $\begin{array}{l}\text { Building codes require emergency and standby systems to } \\
\text { provide backup power for building systems, depending on } \\
\text { building occupancy type, facility use, and critical function. }\end{array}$ \\
\hline \multirow{3}{*}{ نُ } & \multirow{3}{*}{$\begin{array}{l}\text { Multifunctional and diverse services to support } \\
\text { community cohesion } \\
\text { - Multifunctional building services and diversified work } \\
\text { patterns } \\
\text { - Multimodal transportation systems } \\
\text { - Recognized building performance in dynamic real estate } \\
\text { market }\end{array}$} & 7 & $\begin{array}{l}\text { GHG emissions per person hour (metric tons/person } \\
\text { hour) }\end{array}$ & Zero & 0.003 metric ton/person hour (205) \\
\hline & & 8 & $\begin{array}{l}\text { Transportation (for services and commuting to work, } \\
\text { except leisure) GHG emissions per person (metric } \\
\text { tons/person) }\end{array}$ & Zero & 4.8 metric tons/person from on-road vehicles (2013) \\
\hline & & 9 & $\begin{array}{l}\text { Percentage of all U.S. buildings disclosing normalized } \\
\text { healthcare cost, productivity indicators, operation cost, } \\
\text { and other performance metrics reflecting buildings' } \\
\text { long-term impacts on environment and humans }\end{array}$ & $100 \%$ of all U.S. buildings & $\begin{array}{l}\text { Fifteen cities in the U.S. have various building energy use } \\
\text { benchmarking and disclosure policies for commercial and } \\
\text { multifamily buildings. The policies impact } 7.5 \% \text { of } \\
\text { commercial floor space in the U.S. }\end{array}$ \\
\hline \multirow{3}{*}{ 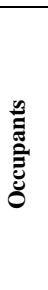 } & \multirow{3}{*}{$\begin{array}{l}\text { Optimized systems for personalized environment and } \\
\text { improved health and wellbeing } \\
\text { - Personalized environment } \\
\text { - Self-learning building systems and intuitive building } \\
\text { operation } \\
\text { - Quantifiable, improved health, well-being, and } \\
\text { productivity }\end{array}$} & 10 & Number of unique automatic control points per person & $\begin{array}{l}\text { Two (one for lighting and one for space } \\
\text { conditioning including air-conditioning and } \\
\text { indoor air quality) }\end{array}$ & $\begin{array}{l}\text { Depending on thermal zone layout and floor plan, } \\
\text { a typical house has one unique automatic control for the } \\
\text { HVAC system (thermostat). The average American } \\
\text { household in } 2015 \text { consisted of } 2.54 \text { people- - that is, } 0.4 \\
\text { control point per person. }\end{array}$ \\
\hline & & 11 & Quality adjusted life year related to buildings & Not yet defined & Not yet defined \\
\hline & & 12 & $\begin{array}{l}\text { Productivity (GDP) per unit energy use per floor area } \\
\text { for commercial buildings }\left(\$ / \mathrm{GJ} \cdot \mathrm{m}^{2}\right)\end{array}$ & 10 times higher & $\begin{array}{l}\$ 1.67 \times 10^{-6} / \text { metric tons } \cdot \mathrm{m}^{2}(2015) \\
\left(\$ 0.15 \times 10^{-6} / \text { metric tons } \cdot \mathrm{ft}^{2}\right)\end{array}$ \\
\hline \multirow[b]{2}{*}{ 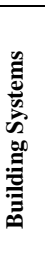 } & \multirow{2}{*}{$\begin{array}{l}\text { Modular, durable construction and interoperable, } \\
\text { adaptive building components } \\
\text { - Modular, durable building components adapting to } \\
\text { changes } \\
\text { - Multi-functional building envelopes } \\
\text { - Programmable and interoperable building components }\end{array}$} & 13 & $\begin{array}{l}\text { Embodied GHG emissions per unit floor area per } \\
\text { service life year (metric tons } / \mathrm{m}^{2} \cdot \text { year ) }\end{array}$ & Zero & $\begin{array}{l}0.011 \mathrm{metric} \text { ton } / \mathrm{m}^{2} \cdot \text { year }(2015) \\
\left(0.001 \mathrm{metric} \text { ton/ } \mathrm{ft}^{2} \text {.year) }\right.\end{array}$ \\
\hline & & 14 & $\begin{array}{l}\text { Level of interoperability among building equipment, } \\
\text { among buildings, and with utilities (quantitative metric } \\
\text { is not yet defined) }\end{array}$ & Not yet defined & Not yet defined \\
\hline
\end{tabular}




\subsection{How do we measure the environmental outcome of future}

\section{buildings?}

Future buildings provide ecological functions on site (such as rainwater collection) or from district services that improve the local and regional ecosystem (such as water purification, $\mathrm{CO}_{2}$ capture, biodiversity support). Design solutions are developed (but not limited) based on natural systems strategies and functionalities. The design outcome can be measured by biodiversity (Metric 1) and water consumption (Metric 2).

Metric 1: Biodiversity measured at building site (unit: 0-1 Simpson's Index of

\section{$\underline{\text { Biodiversity) }}$}

Target: For new construction, predevelopment level just prior to building construction; for $\underline{\text { retrofit, maintain or exceed pre-renovation level (Baseline: Depending on the inhabited biotopes }}$ and regional climate)

A building's interaction with the natural environment can be measured by its ecological impact and integration, i.e., the extent to which a building allows the environment to persist in its unadulterated state. The metrics should reflect how a building minimizes its load into nature and improves the environment with its outflows. Biodiversity loss is listed as one of the three planetary boundaries (climate change, biological diversity, and nitrogen input to the biosphere) that have been transgressed [35].

The richness and evenness of local species can be measured in indices such as Simpson's Index of Diversity (values range from 0 to 1 , where higher numbers represent greater sample diversity) [36], the Shannon Index [37], and their variations [38]. For example, a case study in Austin, Texas, shows a Simpson's Index of Diversity value of 0.9 in city parks and 0.8 on the campus of Austin State University, indicating that city parks have greater diversity [39]. However, interpretation of a diversity index depends on the studied biological group, the regional climate, and the natural range of index variation in the involved taxonomical group in different 
ecosystems. A diversity index could be high for one taxonomic group but low for another ecosystem where the environment is more constant and predictable. Therefore, it is difficult to define a universal baseline and target when the inhabited biotopes and regional climate are unknown. Future buildings are expected to minimize their disturbance of local habitats and maintain the biodiversity level of a building site and its immediate surroundings at least at the predevelopment level just prior to building construction.

\section{Metric 2: Imported daily water consumption per person (unit: liters/person)}

\section{Target: $20 \%$ of today's level (Baseline: 518 liters/person in 2010)}

Water use can be tracked in multiple ways, such as water use per unit area, water use per occupant, or percentage of water use from storm water (rainwater) or indoor water (recycling). The U.S. Green Building Council's Leadership in Energy and Environmental Design (LEED) certification program requires limiting or eliminating the use of potable water for landscape irrigation and sewage conveyance [17]. The Living Future Challenge requires that $100 \%$ of a building's water be supplied by captured precipitation or other natural closed-loop water systems [40].

Considering various geographic locations and site conditions, imported water consumption per person is an effective metric for measuring the ultimate outcome of water conservation and onsite treatment. In 2010, an estimated 1,344 billion liters/day (355 billion gallons/day) of water were withdrawn for all uses in the U.S. [41]. This total includes fresh and saline water from ground and surface sources. Public-supply water is delivered to users for domestic, commercial, and industrial purposes, and also is used for public services and system losses. Public-supply water $(12 \%)$ was the third largest water use category after thermoelectric power generation (45\%) and irrigation (33\%). Table 2 shows the daily imported water consumption in the building sector and the calculated water use per person. The 2010 value, 518 liters/person (137 gallons/person), is used as today's baseline. 
Table 2. Daily water consumption in building sector.

\begin{tabular}{|c|c|c|c|c|c|c|c|c|c|}
\hline \multirow{3}{*}{ Year } & \multirow{3}{*}{$\begin{array}{c}\text { Total Water } \\
\text { Withdrawal } \\
\begin{array}{c}\text { (billion } \\
\text { liters/day) }\end{array}\end{array}$} & \multicolumn{6}{|c|}{ Water Consumption in Building Sector } & \multirow{3}{*}{$\begin{array}{c}\text { Population } \\
\text { (million) }\end{array}$} & \multirow{3}{*}{$\begin{array}{c}\text { Water } \\
\text { Consumption } \\
\text { per Person } \\
\text { (Building } \\
\text { Sector) } \\
\text { (liters/day) }\end{array}$} \\
\hline & & \multicolumn{2}{|c|}{ Residential } & \multicolumn{2}{|c|}{ Commercial } & \multicolumn{2}{|c|}{ All Buildings } & & \\
\hline & & $\begin{array}{l}\% \text { of } \\
\text { total }\end{array}$ & $\begin{array}{c}\text { (billion } \\
\text { liters/day) }\end{array}$ & $\begin{array}{l}\% \text { of } \\
\text { total }\end{array}$ & $\begin{array}{c}\text { (billion } \\
\text { liters/day) }\end{array}$ & $\begin{array}{l}\% \text { of } \\
\text { total }\end{array}$ & $\begin{array}{l}\text { (billion } \\
\text { liters/day) }\end{array}$ & & \\
\hline 1950 & 681 & & & & & & & 152 & \\
\hline 1955 & 908 & & & & & & & 166 & \\
\hline 1960 & 1,022 & & & & & & & 181 & \\
\hline 1965 & 1,173 & & & & & & & 194 & \\
\hline 1970 & 1,401 & & & & & & & 205 & \\
\hline 1975 & 1,590 & & & & & & & 216 & \\
\hline 1980 & 1,628 & & & & & & & 228 & \\
\hline 1985 & 1,503 & $6.1 \%$ & 92 & $1.7 \%$ & 26 & $7.8 \%$ & 117 & 239 & 490 \\
\hline 1990 & 1,529 & $6.2 \%$ & 95 & $2.0 \%$ & 31 & $8.2 \%$ & 125 & 251 & 500 \\
\hline 1995 & 1,507 & $6.5 \%$ & 98 & $2.4 \%$ & 36 & $8.9 \%$ & 134 & 264 & 508 \\
\hline 2000 & 1,563 & $6.9 \%$ & 108 & $2.5 \% *$ & 39 & $9.4 \%$ & 147 & 282 & 521 \\
\hline 2005 & 1,548 & $7.2 \%$ & 111 & $2.5 \% *$ & 39 & $9.7 \%$ & 150 & 296 & 508 \\
\hline 2010 & 1,344 & $7.7 \%$ & 104 & $4.2 \% *$ & 56 & $10.2 \%$ & 160 & 309 & 518 \\
\hline $\begin{array}{l}\text { The gre } \\
* \text { The I } \\
\text { Buildin } \\
2005 \text { (h } \\
\text { Data sc } \\
\text { Buildin } \\
\text { Water } \\
\text { Populat }\end{array}$ & $\begin{array}{l}\text { cells indicate th } \\
\text { S. Geological S } \\
\text { Energy Data B } \\
\text { p://buildingsdat } \\
\text { Irces: } \\
\text { Sector Water C } \\
\text { ithdraw: http://p } \\
\text { on: http://www. }\end{array}$ & $\begin{array}{l}\text { t data at } \\
\text { vey did } \\
\text { k. The } \\
\text { oook.ere } \\
\text { nsumpti } \\
\text { bs.usgs } \\
\text { nsus.go }\end{array}$ & $\begin{array}{l}\text { not availabl } \\
\text { t estimate } \\
10 \text { estimate } \\
\text { doe.gov/Ch } \\
\text { : http://buil } \\
\text { v/circ/1405 } \\
\text { oopest/data/ }\end{array}$ & $\begin{array}{l}\text { nmercial } \\
\text { based on } \\
\text { terIntro8 }\end{array}$ & $\begin{array}{l}\text { ctor use af } \\
005 \text { and ave } \\
\text { px). } \\
\text { x.eren.doe. } \\
\text { ex.html }\end{array}$ & $\begin{array}{l}\text { 1995. Th } \\
\text { ye annua } \\
\text { /TableV }\end{array}$ & $\begin{array}{l}2000 \text { and } 2 \\
\text { rowth in w } \\
\text { w.aspx?tabl }\end{array}$ & $\begin{array}{l}5 \text { estimates are } \\
\text { er consumptior } \\
8.1 .1\end{array}$ & $\begin{array}{l}\text { ased on the } \\
\text { rom } 1985 \text { to }\end{array}$ \\
\hline
\end{tabular}

Future buildings are expected to reduce the imported water consumption per person significantly compared with today's levels. With $20 \%$ water use reduction within reach today and $100 \%$ reduction feasible at some locations, the 100 -year target is $80 \%$ reduction. The metric reflects the outcome of combined strategies for reducing water use for irrigation, sewage, and cooling and increasing the capacity of onsite water treatment and storm water management.

\subsection{How do we measure the interaction of future buildings with the}

\section{natural environment?}

The interaction of human and natural systems in the built environment is reflected in the ability of future buildings to continuously sense and monitor outdoor environmental conditions (such as water quality, outdoor air quality) and constantly track and control their aggregated impact on the micro- and macro-environments (Metric 3). 


\section{Metric 3: Percentage of all U.S. buildings tracking energy and water consumption,}

GHG emissions (including buildings and occupant commutes), indicators of indoor and outdoor air quality, and impact on microenvironment in real time (unit: percent)

Target: 100\% of U.S. commercial and residential buildings (Baseline: $43 \%$ homes with $\underline{\text { smart meters in } 2014 ; 43 \% \text { commercial floor space with building automation systems [BASs] in }}$ $\underline{2012 ; 50 \% \text { of buildings with integrated outdoor sensors to monitor micro-climate conditions) }}$

A building's tracking capability refers to its self-measurement of net site and source energy consumption, water consumption, GHG and criteria pollutant emissions, and other interactions with the natural environment in real-time. It also includes aggregated environmental impacts, such as urban heat island reduction from technological and integrated actions from nature (e.g., green roofs).

Today's effort in real-time measurement is mostly limited to energy and technological advances in integrated sensors. Currently, there are inadequate data about how many buildings are actually tracking their real-time energy consumption. The number of smart meters and BASs indirectly indicates that over $40 \%$ of floor space has tracking capabilities today. As of 2015 , more than about 64.7 million advanced (smart) metering infrastructures (AMI) had been installed in the U.S. [42], About $88 \%$ of the AMI installations were residential customer installations, covering $43 \%$ of U.S. homes [43]. In 2012, $14 \%$ of commercial buildings, representing $43 \%$ of the commercial floor space, were equipped with BASs for HVAC, and less than 5\% of floor space had automated lighting controls [44], [45]. BASs are mostly installed in larger buildings (see Table 3), which usually use more energy than smaller buildings and feature more complex systems. The 2012 Commercial Buildings Energy Consumption Survey (CBECS) indicated increased installations of BASs on both HVAC and lighting equipment. 
Table 3. Penetration rate of BASs in commercial buildings.

\begin{tabular}{|c|c|c|c|c|c|c|c|}
\hline \multicolumn{4}{|c|}{2003 Survey } & \multicolumn{4}{|c|}{2012 Survey } \\
\hline Building Size & $\begin{array}{c}\text { Percentage of Total } \\
\text { Commercial Floor } \\
\text { Area }\end{array}$ & $\begin{array}{l}\text { HVAC } \\
\text { BAS }\end{array}$ & $\begin{array}{l}\text { Lighting } \\
\text { BAS }\end{array}$ & $\begin{array}{c}\text { Percentage of } \\
\text { Total Commercial } \\
\text { Floor Area }\end{array}$ & $\begin{array}{l}\text { Heating } \\
\text { BAS }\end{array}$ & $\begin{array}{l}\text { Cooling } \\
\text { BAS }\end{array}$ & $\begin{array}{l}\text { Lighting } \\
\text { BAS }\end{array}$ \\
\hline All & $100 \%$ & $18 \%$ & $4.9 \%$ & $100 \%$ & $43 \%$ & $16 \%$ & $14 \%$ \\
\hline $\begin{array}{l}\text { Over } 9,290 \mathrm{~m}^{2} \\
\left(100,000 \mathrm{ft}^{2}\right)\end{array}$ & $35 \%$ & $43 \%$ & $12 \%$ & $35 \%$ & & & \\
\hline $\begin{array}{c}\text { Below } 9,290 \mathrm{~m}^{2} \\
\left(100,000 \mathrm{ft}^{2}\right)\end{array}$ & $65 \%$ & $5 \%$ & $1 \%$ & $65 \%$ & & & \\
\hline \multicolumn{8}{|c|}{ The grey cells indicate that data are not available. } \\
\hline \multicolumn{7}{|c|}{$\begin{array}{l}\text { Commercial Buildings Energy Consumption Survey }(2003,2012) \text { : } \\
\text { https://www.eia.gov/consumption/commercial/data/2003/index.cfm? }\end{array}$} & \\
\hline
\end{tabular}

Future buildings are expected to be equipped with active, real-time tracking and monitoring systems with sufficient system and subsystem detail to support accurate diagnostics and prognostics relative to meeting goals in other metrics. The tracking capability and the real-time data enable buildings to receive feedback from their microenvironment (i.e., the tolerant local environment to building systems) and adjust their "environmental behavior."

\subsection{How do we measure the optimized energy outcome of future}

\section{buildings?}

Optimized energy outcomes are measured in terms of the net source energy consumption of buildings (Metric 4) within a connected district and the amount of energy that can be transacted (Metric 5) between buildings to reach the overall energy performance goal.

\section{Metric 4: Average operating GHG emissions per unit floor area (unit: metric ton/m ${ }^{2}$ )}

\section{Target: Zero (Baseline: 0.072 metric ton $/ \mathrm{m}^{2}$ [2015])}

Buildings' GHG emissions and their source energy use are closely related. The ultimate goal is to reduce a building's negative impact on the environment while maintaining reliable and sustainable energy supplies. A metric that uses GHG emissions rather than source energy includes others strategies to mitigate or defer global warming, such as carbon sequestration.

In 2015, U.S. GHG emissions totaled 6,586 million metric tons of carbon dioxide equivalent [46]. Buildings accounted for approximately $30 \%$ of the total GHG emissions (1,893 million 
metric tons). The estimated building floor area was 26,438 million $\mathrm{m}^{2}\left(284,469\right.$ million $\left.\mathrm{ft}^{2}\right)$; therefore, the calculated baseline for Metric 4 is 0.072 metric ton $/ \mathrm{m}^{2}\left(0.007\right.$ metric ton $\left./ \mathrm{ft}^{2}\right)$. Table 4 shows the trends of GHG emissions related to buildings from 1990 to 2015 . The commercial and residential floor spaces have been steadily growing (except that the U.S. Energy Information Administration's estimates of floor area in 2012 and 2013 are slightly lower than the previous years). GHG emissions per unit floor area have remained nearly constant.

Table 4. Trends of operating GHG emissions related to buildings.

\begin{tabular}{|c|c|c|c|c|c|c|c|c|c|c|c|}
\hline \multirow[t]{3}{*}{ Year } & \multicolumn{3}{|c|}{ Residential Buildings } & \multicolumn{3}{|c|}{ Commercial Buildings } & \multicolumn{5}{|c|}{ All Buildings } \\
\hline & GHG & $\begin{array}{l}\text { Floor } \\
\text { Space }\end{array}$ & $\begin{array}{c}\text { GHG per } \\
\text { Floor } \\
\text { Area }\end{array}$ & GHG & $\begin{array}{l}\text { Floor } \\
\text { Space }\end{array}$ & $\begin{array}{c}\text { GHG } \\
\text { per } \\
\text { Floor } \\
\text { Area } \\
\end{array}$ & $\begin{array}{c}\text { GHG } \\
\text { (Buildings) }\end{array}$ & $\begin{array}{c}\text { GHG } \\
\text { (U.S. } \\
\text { Overall) }\end{array}$ & $\begin{array}{c}\% \text { from } \\
\text { Buildings }\end{array}$ & $\begin{array}{l}\text { Floor } \\
\text { Space }\end{array}$ & $\begin{array}{l}\text { GHG } \\
\text { per } \\
\text { Floor } \\
\text { Area } \\
\end{array}$ \\
\hline & $\begin{array}{l}\text { (million } \\
\text { metric } \\
\text { tons) }\end{array}$ & $\begin{array}{l}\text { (million } \\
\mathrm{m}^{2} \text { ) }\end{array}$ & $\begin{array}{l}\text { (metric } \\
\text { tons } / \mathrm{m}^{2} \text { ) }\end{array}$ & $\begin{array}{c}\text { (million } \\
\text { metric } \\
\text { tons) }\end{array}$ & $\begin{array}{l}\text { (million } \\
\mathrm{m}^{2} \text { ) }\end{array}$ & $\begin{array}{l}\text { (metric } \\
\text { tons } / \mathrm{m}^{2} \text { ) }\end{array}$ & $\begin{array}{l}\text { (million } \\
\text { metric tons) }\end{array}$ & $\begin{array}{l}\text { (million } \\
\text { metric tons) }\end{array}$ & $(\%)$ & $\begin{array}{l}\text { (million } \\
\mathrm{m}^{2} \text { ) }\end{array}$ & $\begin{array}{c}\text { (metric } \\
\text { tons } / \mathrm{m}^{2} \text { ) }\end{array}$ \\
\hline 1990 & 931 & 15,725 & 0.059 & 755 & 5,976 & 0.126 & 1,687 & 6,301 & $27 \%$ & 21,701 & 0.078 \\
\hline 1995 & 1,051 & $16,264^{*}$ & 0.065 & 854 & 5,462 & 0.156 & 1,904 & 5,085 & $37 \%$ & 21,726 & 0.088 \\
\hline 2000 & 1,200 & $19,333^{*}$ & 0.062 & 1,025 & 6,366 & 0.161 & 2,225 & 5,623 & $40 \%$ & 25,699 & 0.087 \\
\hline 2005 & 1,214 & 23,838 & 0.051 & 1,027 & $6,907^{*}$ & 0.149 & 2,241 & 7,350 & $30 \%$ & 30,746 & 0.073 \\
\hline 2010 & 1,175 & $19,767 *$ & 0.059 & 993 & 7,528 & 0.132 & 2,168 & 6,899 & $31 \%$ & 27,294 & 0.079 \\
\hline 2011 & 1,118 & $18,724^{*}$ & 0.060 & 959 & $7,807 *$ & 0.123 & 2,077 & 6,777 & $31 \%$ & 26,531 & 0.078 \\
\hline 2012 & 1,008 & 17,682 & 0.057 & 897 & 8,086 & 0.111 & 1,906 & 6,545 & $29 \%$ & 25,768 & 0.074 \\
\hline 2013 & 1,070 & 17,830 & 0.060 & 933 & 7,695 & 0.121 & 2,004 & 6,673 & $30 \%$ & 25,525 & 0.078 \\
\hline 2014 & 1,080 & 17,988 & 0.060 & 937 & 83,100 & 0.121 & 2,018 & 6736.3 & $30 \%$ & 25,711 & 0.078 \\
\hline 2015 & 1,004 & 18,176 & 0.055 & 889 & 88,900 & 0.108 & 1,893 & 6586.2 & $29 \%$ & 26,438 & 0.072 \\
\hline $\begin{array}{l}\text { * Interp } \\
\text { Data so } \\
\text { Inventor } \\
\text { Inventor } \\
\text { DRAFT } \\
02 / \text { docu } \\
\text { Building } \\
\text { Annual } \\
\text { Annual } \\
\text { Comme } \\
\text { Residen }\end{array}$ & $\begin{array}{l}\text { ted based o } \\
\text { ces: } \\
\text { of U.S. Gree } \\
\text { 2015-Main- } \\
\text { ventory of } \\
\text { ents/2017 c } \\
\text { Energy Dat } \\
\text { ergy Outloo } \\
\text { ergy Outloo } \\
\text { al Buildings } \\
1 \text { Buildings }\end{array}$ & $\begin{array}{l}\text { the existin } \\
\text { nhouse Gas } \\
\text { Text.pdf (19 } \\
\text { J.S. Greenh } \\
\text { mplete rep } \\
\text { Book: http } \\
\text { k 2015: http } \\
\text { k 2017: http }\end{array}$ & $\begin{array}{l}\text { survey and a } \\
\text { Emissions an } \\
\text { 0-2013 data } \\
\text { use Gas Emi } \\
\text { rt.pdf (2014 } \\
\text { /buildingsdat } \\
\text { //www.eia.g } \\
\text { ://www.eia.g }\end{array}$ & $\begin{array}{l}\text { ailable pro } \\
\text { Sinks: } 199 \\
\text { yere derivec } \\
\text { ions and Si } \\
\text { ad } 2015 \text { da } \\
\text { book.eren.c } \\
\text { /forecasts/s } \\
\text { v/outlooks/ }\end{array}$ & $\begin{array}{l}\text { ctions. } \\
\text {-2013 (Apr } \\
\text { from the 20 } \\
\text { ks: } 1990-2 \\
\text { were deriv } \\
\text { e.gov/Tab } \\
\text { eo/pdf/0383 } \\
\text { eo/pdf/038 }\end{array}$ & $\begin{array}{l}\text { 2015): http } \\
5 \text { report) } \\
5 \text { (Februar } \\
1 \text { from the } \\
\text { View.aspx? } \\
\text { 2015).pdf ( } \\
\text { 2017).pdf } \\
\text { onsumption }\end{array}$ & $\begin{array}{l}\text { Nww3.epa.gov } \\
\text { 017): https://y } \\
7 \text { report) } \\
\text { le=3.2.1 } \\
0-2013 \text { data } \\
14 \text { and } 2015 \mathrm{~d} \\
\text { mmercial/ }\end{array}$ & $\begin{array}{l}\text { matechange/D } \\
\text { vepa.gov/sites } \\
\text { derived from } \\
\text { were derived } \mathrm{f}\end{array}$ & $\begin{array}{l}\text { Nnloads/ghg } \\
\text { roduction/fil } \\
\text { e } 2015 \text { repor } \\
m \text { the } 2017\end{array}$ & $\begin{array}{l}\text { missions/U } \\
\text { s/2017- }\end{array}$ & GHG- \\
\hline
\end{tabular}

Based on the building stock turnover and considering the various building functions and site conditions, the target for each building is to reduce its energy-consuming loads as much as feasible, so that they can be met by renewable energy generated on site or from the local grid. We can expect that, in aggregate, building communities can reach net zero, i.e., an energy-efficient 
community where, on a source energy basis, the actual annual delivered energy is less than or equal to the onsite renewable exported energy [47]. To reach the zero-emission target in 100 years, more aggressive actions are required. According to the International Energy Agency, a combination of technology and policy actions can reduce GHG emissions to a quarter of the current level and achieve the goal of limiting global temperature rise to $2^{\circ} \mathrm{C}$ by 2050 [1].

\section{Metric 5: Capacity to reduce peak load, and to transact the remaining peak load (unit:}

\section{percent)}

Target: Reduce peak load by 50\%, and transact 50\% of the remaining peak load (Baseline:

\section{$\underline{\text { Nationwide peak summer demand in buildings is } 29.7 \mathrm{~W} / \mathrm{m}^{2} \text { in } 2013 \text { ) }}$}

Transactable load measures the overall amount of energy that is dispatchable to serve other buildings within the grid. The scale and configuration of the electric grid will vary with local conditions, but the infrastructure for generation and demand is highly flexible and controllable on a very short time scale to meet all grid management needs. This metric defines the degree to which a building should manage its peak demand on site. It also reflects the degree to which a building can rely on the grid to meet its peak demand. Each building's capability to control its demand is essential to meeting the overall net zero goal. Future buildings on average are expected to meet $75 \%$ of their demand from onsite generation and $25 \%$ from the grid, although this split highly depends on building functions and site conditions.

The estimated distributed solar photovoltaic (PV) capacity (net summer capacity) is 6,221.4 megawatts (2870.8 from residential, 2771.8 from commercial, and 578.8 from industrial) in 2014 [48] - less than $1 \%$ of the total electricity generation capacity (1,029 gigawatts in 2013). Solar PV capacity is estimated to grow by an average of 30\% per year from 2013 through 2016 in the residential sector and $9 \%$ in the commercial sector. With the expiration of the $30 \%$ U.S. federal investment tax credit at the end of 2016, the average annual growth of PV capacity in residential and commercial buildings is projected to be $6 \%$ in both sectors through 2040. In comparison, the 
total electric power sector capacity is projected to grow at an annual rate of $0.5 \%$ through 2040 [49].

\subsection{How do we measure the resilience of future buildings?}

Resilience has a broad range of implications, such as recovery time during extreme events, emergency supplies in buildings, or injuries during construction (safety), operation (ergonomics), and deconstruction (catastrophic events). The suggested metric (Metric 6) is focused on the capability of connected buildings to use one another as backup systems to reach a certain redundancy level.

\section{Metric 6: Percentage of loads within a grid that can operate without external energy}

\section{supply within a time period (unit: percent)}

Target: $100 \%$ critical loads can operate at full functions for a week and up to two weeks. $\underline{50 \% \text { noncritical loads can operate at reduced functions for } 48 \text { hours (or } 25 \% \text { for a week) }}$

\section{$\underline{\text { (Baseline: None) }}$}

Commercial building codes currently require emergency and standby systems to provide backup power for building systems to ensure that life safety systems and critical equipment can maintain their operation during a power outage. Specific requirements vary based on building occupancy type, facility use, and critical function (such as fire alarms and exhaust ventilation, smoke control systems, and means of egress illumination, among others). For example, NFPA 70, National Electrical Code, has addressed the need for emergency power in buildings to help people exit safely [50]. The 2008 edition of NFPA 70 added Article 708, Critical Operations Power Systems, to provide guidance on designing facilities that require continuous operation for reasons such as public safety, emergency management, and national security (e.g., air traffic control centers, hospitals, 911 call centers) [51]. Currently, backup power is supplied by a generator that runs on diesel, gasoline, natural gas, or liquid propane gas. An uninterruptible power supply is also used to store electricity in batteries or a flywheel [52]. 
Installing redundant power systems is costly, especially in aging facilities. Microgrids have become an important opportunity in the last 10 to 15 years due to an increase in disruptive weather events such as Hurricane Sandy in 2012. In addition to reducing energy consumption and increasing distributed generation to cover peak load, microgrids that integrate redundant generation and distribution, smart switches and automation, and power storage can provide a tiered, resilient power system that supports a community during a mission-critical event [53].

\subsection{How do we measure the flexibility of future buildings?}

Currently, the real estate market tracks quarterly vacancy rates by region; for example, U.S. office space had an average vacancy rate of $10.4 \%$ in downtown areas and $15 \%$ in suburban areas in the third quarter of 2015 [54]. There is no publicly available record of a building's actual space

utilization rate when it is leased or fully operated. Full utilization of existing buildings will reduce the waste of energy and other resources to maintain empty space and, more importantly, the demand for new construction. Future buildings are more multifunctional and flexible to meet the changing tenant needs (e.g., service towards work/life balance) over time and accommodate the changing demography (e.g., older population). A building's capacity to support these needs can be reflected in its GHG emissions associated with actual utilization (Metric 7).

\section{Metric 7: GHG emissions per person hour (unit: metric tons/person hour)}

\section{Target: Zero (Baseline: 0.003 metric ton/person hour in 2015)}

The proposed metric uses GHG emissions per person hour to represent how productively a building is used. The baseline depends on building functions. Based on the CBECS 2012 data, the total number of occupants in commercial buildings was 88.182 million. The weighted mean operating hours per week was 65 , that is, 3,380 hours per year. The operating GHG emissions of commercial buildings in 2012 was 897 million metric tons (Table 4). Therefore, the calculated baseline is 0.003 metric ton/person hour (2012). Table 5 shows the trends of GHG emissions 
associated with building operating hours and occupancy from 1990 to 2013. The emissions have decreased slightly in the past 10 years.

Table 5. GHG emissions related to building occupancy (commercial buildings).

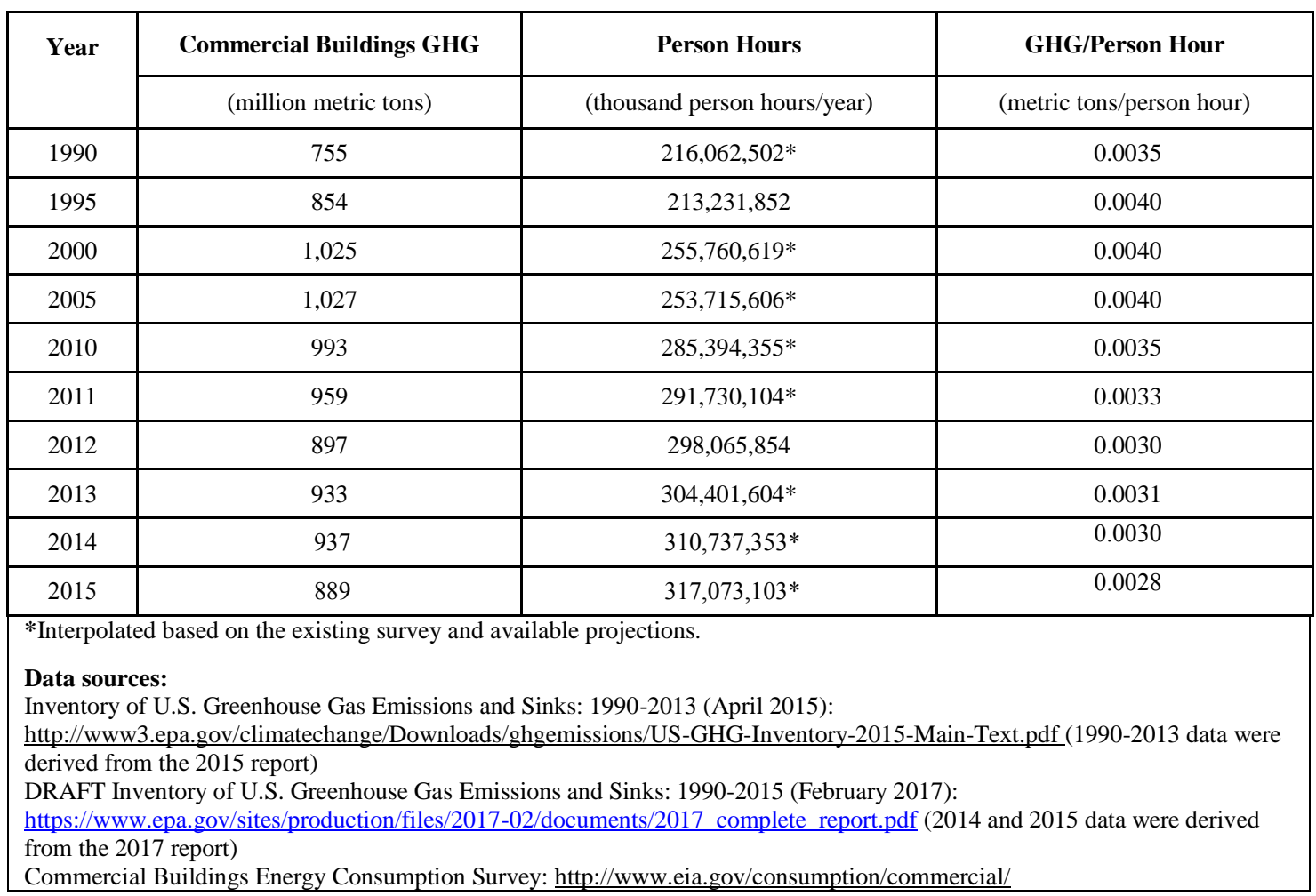

\subsection{How do we measure the integration of future buildings with}

\section{transportation?}

Buildings are connected by transportation systems and therefore have a direct impact on transportation energy use and GHG emissions. Buildings' connectivity to city transportation systems is currently measured in walkability and access to public transportation (e.g., walk score, bike score, and transit score) [55]. It is possible to track the average distance traveled per person to and from a building or the number and percentage of kilometers (miles) traveled per person per year, by mode. However, the capacity and utilization rate of different transportation modes (e.g., vehicles of different types) and infrastructure (e.g., roads, paths, rails) vary by city and are limited by the existing infrastructure. It is difficult to create a cross comparison and common target. The 
number of parking spaces and percentage of property or total square footage dedicated to cars (e.g., garages, driveways, parking) are other ways to evaluate land use for transportation. These metrics are based on the assumption that personal vehicles should be limited. With more electric cars being integrated into building energy systems and utility grids, the connection between transportation and building energy use becomes tighter. Measuring transportation GHG (Metric 8) reflects not only the mode of transportation, but also building location and how buildings are connected to services and supplies.

\section{Metric 8: Transportation (for services and commuting to work, except leisure) GHG}

\section{emissions per person (unit: metric tons/person)}

\section{Target: Zero (Baseline: 4.8 metric tons/person in 2013)}

Transportation GHG emissions per trip, per person, or per kilometer (mile) traveled are likely to decrease with the growth of electric vehicles; new, more efficient technologies (e.g., automated vehicles); renewable energy generation; and remote communication. Remote communication will also reduce the time that people have to spend in a centralized work location and in commuting.

Transportation represented $27 \%$ of total U.S. GHG emissions in 2014, and on-road vehicles accounted for $85 \%$ of total transportation GHG emissions [56]. Due to the lack of data on transportation GHG emissions for services and commuting to work, on-road vehicles are used to provide a relevant baseline, i.e., 4.8 metric tons/person (Table 6).

Table 6. Trends of GHG emissions related to on-road vehicles.

\begin{tabular}{|c|c|c|c|c|c|}
\hline \multirow{2}{*}{ Year } & $\begin{array}{c}\text { On-Road } \\
\text { Vehicles }\end{array}$ & $\begin{array}{c}\text { Transportation } \\
\text { Total }\end{array}$ & $\begin{array}{c}\text { \% from On-Road } \\
\text { Vehicles }\end{array}$ & Population & $\begin{array}{c}\text { GHG Emissions per } \\
\text { Person }\end{array}$ \\
\cline { 2 - 6 } & $\begin{array}{c}\text { (million metric } \\
\text { tons) }\end{array}$ & (million metric tons) & $(\%)$ & (million) & (metric tons/person) \\
\hline 1990 & $1,233.5$ & 1551.3 & $80 \%$ & 249.6 & 4.9 \\
\hline 1995 & $1,370.5$ & 1695.2 & $81 \%$ & 266.3 & 5.1 \\
\hline 2000 & $1,572.8$ & 1923.2 & $82 \%$ & 282.2 & 5.6 \\
\hline 2005 & $1,672.4$ & 1999.6 & $84 \%$ & 295.5 & 5.7 \\
\hline 2010 & $1,541.7$ & 1827.4 & $84 \%$ & 309.3 & 5.0 \\
\hline 2011 & $1,540.9$ & 1833.7 & $84 \%$ & 311.7 & 4.9 \\
\hline 2012 & $1,517.6$ & $1,795.9$ & $85 \%$ & 311.7 & 4.9 \\
\hline
\end{tabular}




\begin{tabular}{|c|c|c|c|c|c|}
\hline 2013 & $1,504.3$ & $1,789.9$ & $84 \%$ & 314.1 & 4.8 \\
\hline 2014 & $1,531.1$ & $1,810.3$ & $85 \%$ & 320.1 & 4.8 \\
\hline Data sources: \\
U.S. Transportation Sector Greenhouse Gas Emissions: \\
Fast Facts: U.S. Transportation Sector GHG Emissions 1990-2012 (https://nepis.epa.gov/Exe/ZyPDF.cgi?Dockey=P100M2GU.pdf) \\
Fast Facts: U.S. Transportation Sector GHG Emissions 1990-2013 (https://nepis.epa.gov/Exe/ZyPDF.cgi?Dockey=P100NNQ9.pdf) \\
Fast Facts: U.S. Transportation Sector GHG Emissions 1990-2014 (https://nepis.epa.gov/Exe/ZyPDF.cgi?Dockey=P100ONBL.pdf) \\
Population: http://www.census.gov/popest/data/historical/index.html \\
\hline
\end{tabular}

Activities contributing to a building's GHG emissions include direct emissions from combustion of fuels (Scope 1); indirect emissions from purchased electricity, heating, and steam (Scope 2); and other indirect emissions from employee activities such as commuting, business travel, and waste disposal. (Scope 3) [57]. A U.S. federal agency currently can capture its Scope 3 employee commute information through the General Services Administration's Commuter Survey and report its emissions to the U.S. Department of Energy's Federal Energy Management Program [58]. The tracking process can become automated with personal mobile devices connected to the transportation systems.

\subsection{How do we measure the asset value of future buildings?}

The market value of future buildings will reflect the long-term positive and negative impacts that a building's handprint (i.e., what we give to the planet when we directly create change for better [18]), footprint (i.e., what we take from the planet when we consume), and usage have in the local and regional environment. Metric 9 evaluates the market aspect of future buildings.

Metric 9: Percentage of all U.S. buildings disclosing normalized healthcare costs, productivity indicators, operation costs, and other performance metrics reflecting buildings' long-term impacts on environment and occupants (unit: percent)

Target: $100 \%$ of U.S. buildings (Baseline: Various benchmarking and disclosure policies for building energy use affect $7.5 \%$ of commercial floor space)

The market value of future buildings will reflect their total cost of ownership and resource capacity (energy, water, ecological function), air quality, carbon footprint, and so forth. The total cost of ownership includes the total cost of a building's design, construction, operation, 
maintenance or renewal, and decommissioning through its useful life [59]. The initial capital cost for a new building comprises about $15 \%$ of the total cost of a building over its 40 -year lifespan, while the operation and maintenance costs make up the remaining $85 \%$ [60]. The concept of total cost of ownership has also been extended to environmental impacts, operational benefits, improved productivity, and improved life-cycle flexibility [61].

Currently, only the average major expenses (i.e., cleaning, repair and maintenance, utilities, roads and grounds, security, administration, and fixed cost) are tracked and benchmarked by building type and location in the BOMA-Kingsley quarterly report [62]. Fifteen cities in the U.S. have various building energy use benchmarking and disclosure policies for commercial and multifamily buildings [63]. These policies impact 56,000 properties and approximately 6.6 billion square feet of floor space in the major real estate markets [64]. This accounts for $7.5 \%$ of the 87.4 billion square feet of commercial floor space [65].

\subsection{How do we measure comfort and healthiness of future buildings?}

Future building designs reflect the adaptation range of the human body, designing not for a single optimized point but for a range that is generally free of discomfort (including thermal comfort, lighting, noise, and indoor air quality). A building's capability to provide an optimized indoor environment and promote health and wellbeing can be measured in Metrics 10 and 11.

\section{Metric 10: Number of unique automatic control points per person (unit: NA)}

Target: Two (one for lighting and one for space conditioning, including air-conditioning and indoor air quality) (Baseline: None)

This metric indicates that occupants can optimize their immediate lighting and thermal environment. However, it does not require additional control from occupants because buildings can automatically learn occupant preferences with experience. All buildings are expected to be equipped with fault detection and diagnostics to identify operating faults and improve performance. They will be able to balance occupant needs and optimize outcomes. 
Currently, HVAC controls are designed based on building thermal zone layout and required indoor ventilation. Residential buildings and older commercial buildings often cannot provide personalized indoor environments because the whole house or the whole floor shares one HVAC control point. A typical house has one control for the HVAC system. The average American household in 2015 consisted of 2.54 people — that is, 0.4 control points per person.

\section{Metric 11: Quality adjusted life year related to buildings (unit: years)}

\section{Target and baseline are yet to be developed.}

Buildings with health-promoting characteristics should be evaluated by metrics used for medical services and healthcare. For example, quality adjusted life year (QALY) [66] assesses the value of medical interventions by measuring the quality and the quantity of life lived; disability adjusted life year (DALY) calculates the potential years of life lost due to premature death, poor health, and disability [67]. Currently DALYs are measured by cause (e.g., 291 communicable maternal, neonatal, and nutritional disorders, non-communicable diseases, and injuries), age, sex, and region [68]. There is inadequate research to establish DALY-to-building linkages, which might include causes associated with physical activity and obesity, indoor air quality [69], access to healthy food, and certain injuries. A metric such as QALY can measure the outcomes of buildings with health-promoting characteristics and capture the physical and psychological benefits, including the full benefits of happiness, ergonomics, thermal comfort, ventilation, lighting, and other factors.

\subsection{How do we measure the productivity of future buildings?}

\section{Metric 12: Productivity (GDP) per unit energy use per floor area (unit: $\$ / \mathbf{G J} \bullet \mathbf{m}^{2}$ )}

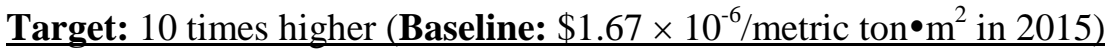

Primary energy use in the U.S. has remained largely flat since 2000, while the gross domestic product (GDP) has continued to grow. The energy productivity reached \$141/GJ (\$149/MMBtu) in 2014 [70]. The building- and transportation-related areas offer the greatest potential—each 
more than one-third of the overall productivity gain. Assuming that the energy productivity can continue growing at the current rate after 2030 [71], the productivity is projected to increase by a factor of 10 in 100 years. Future buildings are expected to contribute at least one-third of the productivity increase.

From 1947 to 2013 , the annual increase in productivity [72] ${ }^{1}$ in the business sector ranged from $1.3 \%$ to $3.2 \%$ [73]. The labor productivity index grew by over five times (from 21 to 107 , measured in output per hour, index $2009=100$ ) in 66 years from 1947 to 2013 [73]. Following this trend, it is possible that the labor productivity index can grow to 237 in the next 100 years, increasing by $120 \%$ compared to today.

In 2015, the U.S. GDP was $\$ 18,037$ billion [74]. The private-services-producing industries contributed to $68.2 \%$ of total GDP [75]. The estimated commercial building floor area in 2015 was 8,262 million $\mathrm{m}^{2}\left(88,900\right.$ million $\left.\mathrm{ft}^{2}\right)$ [76] and the GHG emissions were 889 metric tons. The

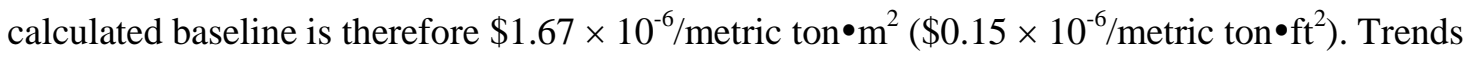
from 1990 through 2015 are presented in Table 7.

Table 7. Trends of productivity and commercial building GHG emissions.

\begin{tabular}{|c|c|c|c|c|c|c|}
\hline \multirow[t]{2}{*}{ Year } & $\begin{array}{l}\text { Gross Domestic } \\
\text { Product }\end{array}$ & $\begin{array}{l}\text { Private-Services- } \\
\text { Producing } \\
\text { Industries* }\end{array}$ & $\begin{array}{l}\% \text { from } \\
\text { Service }\end{array}$ & $\begin{array}{c}\text { Commercial } \\
\text { Building GHG }\end{array}$ & $\begin{array}{l}\text { Commercial } \\
\text { Building Floor } \\
\text { Area }\end{array}$ & $\begin{array}{l}\text { Productivity per } \\
\text { Unit Emissions } \\
\text { per Floor Area }\end{array}$ \\
\hline & $\begin{array}{l}\text { (billions of current } \\
\text { U.S. dollars) }\end{array}$ & $\begin{array}{l}\text { (billions of current } \\
\text { U.S. dollars) }\end{array}$ & $(\%)$ & $\begin{array}{l}\text { (million metric } \\
\text { tons) }\end{array}$ & $\left(\right.$ million $\mathrm{m}^{2}$ ) & $\left(\$ / \mathrm{GHG} \cdot \mathrm{m}^{2}\right)$ \\
\hline 1990 & 5,980 & 3,981 & $62.8 \%$ & 755 & 5,976 & $0.83 \times 10^{-6}$ \\
\hline 1995 & 7,664 & 5,102 & $64.6 \%$ & 854 & 5,462 & $1.06 \times 10^{-6}$ \\
\hline 2000 & 10,285 & 6,847 & $65.4 \%$ & 1,025 & 6,366 & $1.03 \times 10^{-6}$ \\
\hline 2005 & 13,094 & 8,717 & $66.1 \%$ & 1,027 & 6,908 & $1.22 \times 10^{-6}$ \\
\hline 2010 & 14,964 & 9,962 & $66.6 \%$ & 993 & 7,528 & $1.33 \times 10^{-6}$ \\
\hline 2011 & 15,518 & 10,299 & $66.4 \%$ & 959 & 7,807 & $1.38 \times 10^{-6}$ \\
\hline 2012 & 16,155 & 10,794 & $66.8 \%$ & 897 & 8,086 & $1.49 \times 10^{-6}$ \\
\hline 2013 & 16,663 & 11,128 & $66.8 \%$ & 933 & 7,695 & $1.55 \times 10^{-6}$ \\
\hline 2014 & 17,393 & 11,659 & $67.0 \%$ & 937 & 7,723 & $1.61 \times 10^{-6}$ \\
\hline 2015 & 18,037 & 12,293 & $68.2 \%$ & 889 & 8,262 & $1.67 \times 10^{-6}$ \\
\hline \multicolumn{7}{|c|}{$\begin{array}{l}\text { * Consists of utilities; wholesale trade; retail trade; transportation and warehousing; information; finance, insurance, real estate, } \\
\text { rental, and leasing; professional and business services; educational services, health care, and social assistance; arts, entertainment, } \\
\text { recreation, accommodation, and food services; and other services, except government. }\end{array}$} \\
\hline \multicolumn{7}{|c|}{ Source } \\
\hline
\end{tabular}

\footnotetext{
${ }^{1}$ Labor productivity, or output per hour, is calculated by dividing an index of real output by an index of hours worked of all persons, including employees, proprietors, and unpaid family workers.
} 
Although GDP in its current format seems not applicable to individual buildings, a revised version with a similar concept can be developed in the future to quantify a building's economic outcome. This metric will need to be considered in the context of what a building is used for. A building will be compared against those with a similar use type and job function. The GDP proposed here can be thought of as the gross overall average.

\subsection{How do we measure the adaptability and interoperability of future buildings?}

Considering the relatively long service life of buildings and the rapid change in technologies and lifestyles, future building components are more adaptable, rather than being disposed of when obsolete. More recyclable building materials and flexible structures allow some buildings to reduce their service life without increasing embodied energy, generating extra waste, and consuming precious natural resources. Metric 13 measures the ability of future buildings to adapt to function or condition (weather, environment) changes over time and their overall recyclability. Metric 14 calls for a uniform way to evaluate interoperability; however, no quantifiable metrics and targets are developed yet.

\section{Metric 13: Embodied GHG emissions per unit floor area per service life year (unit:}

\section{$\underline{\text { metric tons } / \mathrm{m}^{2} \bullet \text { year) }}$}

Target: Zero (Baseline: 0.0168 metric ton $/ \mathrm{m}^{2} \bullet$ year in 2013 )

The embodied energy or carbon is associated with energy or GHG emitted to construct, renovate, and demolish a building, including extraction of raw materials, manufacture of building products, and construction of the building. The use of durable materials or recyclable materials can reduce refurbishment cycles, thereby reducing GHG emissions in the long term. The goal is to extend a building's adaptability during its service life to avoid unnecessary building upgrades, renovations, and new construction, and thereby reduce embodied energy and resource consumption. 
The amount of embodied energy or carbon in buildings varies considerably depending on suppliers, construction methods, site location, and other factors. For example, the embodied energy of a typical home in the U.S. is estimated to be $15 \%$ of total energy use over its lifetime [77], and similarly for a new university building in Australia [78]. For a typical three-bedroom detached house in the U.K. in 1991, the embodied energy was estimated to account for approximately $10 \%$ of total life cycle energy over a 60 -year period [79]. For new, well-insulated, energy-efficient buildings, embodied energy can account for $40 \%$ to $60 \%$ of the total life cycle or even exceed the operational energy use [80]. Compared with the initial embodied energy (from construction), the recurring embodied energy (from maintenance, renovation, and demolition) is more difficult to estimate. Using a model based on Canadian construction of a generic $4,620 \mathrm{~m}^{2}$ $\left(50,000 \mathrm{ft}^{2}\right)$ three-story office building, Cole and Kernan estimated that such recurring embodied energy will represent about $144 \%$ of the initial embodied energy by year 50 and rise to $325 \%$ by year $100[81]$.

To calculate today's baseline, we assume that embodied GHG emissions account for approximately $15 \%$ of total emissions over a building's service life. Using Metric 4 (0.072 metric ton $/ \mathrm{m}^{2}$ from building operation), the baseline for Metric 13 is 0.011 metric ton $/ \mathrm{m}^{2} \bullet$ year $(0.001$ metric ton $/ \mathrm{ft}^{2} \cdot$ year).

\section{Metric 14: Level of interoperability among building equipment, among buildings, and}

\section{$\underline{\text { with utilities }}$}

The need for interoperability of buildings' HVAC equipment, lighting, miscellaneous electric loads, and associated sensors and actuators with the BAS is widely recognized [82]-[83], and future buildings will require similar interoperability with other buildings and utilities. Interoperability, in general, is facilitated by using open-source protocols. Since there is currently no well-defined measure of interoperability for buildings, such a measure must first be developed and quantified to define a suitable 100-year target. 


\section{Summary and Conclusions}

Our vision looks beyond the current century and sees buildings as active components of larger districts, adapting to changing environmental conditions and demography, supporting occupant health and well-being, and using resources efficiently to provide ubiquitous building services. We anticipate that climate change, population growth, and resource scarcity will be important design drivers, and that economic, social, health, and productivity factors, equipment and information technologies, and utility infrastructure must be considered for the buildings of the future. The five categories of future building characteristics integrate multidisciplinary knowledge (i.e., environmental science, climatology, public health science, building and urban science) and seek proactive, scalable approaches for mainstream buildings while considering environmental, economic, and social constraints. Table 1 summarizes the desired future building characteristics and related metrics, baseline values, and 100-year nationwide U.S. targets. The metrics are intended to establish a quantitative framework to integrate various aspects of building performance. Near-term development goals that emphasize one target while sacrificing others may jeopardize future development.

Future buildings will not be generic and will vary according to their local context and purpose. For example, buildings of the future may have an overall goal of being "net positive"; however, no universal solution or uniform goal (such as zero GHG emission) fits all buildings. Certain building characteristics will be more important than others, depending on regional climate and ecosystem, building function, settlement patterns, cultural backgrounds, market conditions, and local policies. Building strategies and performance metrics need to adapt to the local context. The proposed 100-year targets are not intended to predict the future state; rather, they initiate a needed dialog to establish goals for future building development. For example, the incremental steps to reach the 100-year targets of zero GHG emissions are as important as the targets themselves. 
The forward-looking metrics and targets discussed in this paper will rely on future technology innovation to realize the vision. On the other hand, integration of existing technologies is as important as new technology development. Some technologies are either not cost-effective today, inhabiting wide adoption, or simply do not have a strong enough value proposition to move consumers to demand them. For example, we can achieve net-zero energy buildings or create smart buildings with today's technologies; however, with the relatively low energy prices common in the U.S., energy cost savings are not the first consideration for most people when in the real estate market. In addition, without a proper infrastructure support (such as value-based utility transaction network, interoperability for connected devices), smart buildings do not yet offer enough value to general consumers. A further challenge is that we do not yet have a means to quantify the non-monetized benefits such as health and wellbeing. The key to success is in determining how technologies can be integrated to balance and advance multiple, and complementary, aspects of the built environment.

The proposed vision intends to expand the conversation about approaches to revolutionize the present constructed environment into an intended sustainable future. The basis for the vision is grounded mostly in U.S. information; however, it is applicable to today's and tomorrow's modern societies. The proposed performance metrics and 100-year targets are intended to motivate future design strategies, inspire technological development, and influence urban planning. A clear, compelling vision aims to initiate more discussions about new design paradigms, innovative operational strategies, and disruptive technologies that could revolutionize the built environment and truly transform buildings into resource assets-fully self-aware, adaptive, and communicative buildings with added market value.

\section{Acknowledgement}

This project was funded by the U.S. Department of Energy, Building Technologies Office. This research project has benefitted from the input of many individuals from various organizations. Special thanks go to all of the organizations and individuals who have actively 
participated in our discussions, shared their ideas, and provided constructive suggestions (http://futurebuildings.labworks.org/people-and-partners.html).

\section{References}

[1] International Energy Agency. Transition to Sustainable Buildings: Strategies and Opportunities to 2050 (Paris, 2013).

[2] International Energy Agency. Transition to Sustainable Buildings: Strategies and Opportunities to 2050 (Paris, 2013). http://www.oecd-ilibrary.org/energy/transition-tosustainable-buildings 9789264202955 -en.

[3] Alstone, P., Gershenson, D., \& Kammen, D.M. Decentralized energy systems for clean electricity access. Nat. Clim. Chang. 5, 305-314 (2015). doi:10.1038/nclimate2512.

[4] Lenton, T.M. Early warning of climate tipping points. Nat. Clim. Chang. 1, 201-209 (2011). doi:10.1038/nclimate1143.

[5] Poff, N.L., et al. Sustainable water management under future uncertainty with ecoengineering decision scaling. Nat. Clim. Chang. 6, 25-34 (2016).

doi:10.1038/nclimate2765.

[6] United Nations. World Urbanization Prospects. (New York, 2014). http://esa.un.org/unpd/wup/Publications/Files/WUP2014-Report.pdf.

[7] Robinson, J.P., Converse, P.E., \& Szalai, A. Everyday life in twelve countries. In Alexandria Szalai, ed., The Use of Time; Daily Activities of Urban and Suburban Populations in Twelve Countries (Mouton, The Hague, 1972, 112-144).

[8] National Resources Defense Council. Water Facts: Climate Change, Water, and Risk: Current Water Demands Are Not Sustainable (Washington, D.C., 2010). http://www.nrdc.org/globalwarming/watersustainability/files/WaterRisk.pdf.

[9] U.S. General Services Administration. The New Sustainable Frontier: Principles of Sustainable Development. (Washington, D.C.: Office of Governmentwide Policy, Office of Real Property Management, 2009). http://www.gsa.gov/graphics/ogp/2009_New_Sustainable_Frontier_Complete_Guide.pdf.

[10] Gudipudi, R., Fluschnik, T., Cantú Ros, A.G., Walther, C., \& Kropp, J.P. City density and CO2 efficiency. Energy Policy 91, 352-361. doi:10.1016/j.enpol.2016.01.015.

[11] Delmas, M.A., \& Pekovic, S. Environmental Standards and Labor Productivity: Understanding the Mechanisms that Sustain Sustainability. J. Organ. Behav. 34, 230-252 (2013). http://onlinelibrary.wiley.com/doi/10.1002/job.1827/pdf.

[12] Bhatta, B., Saraswati, S., \& Bandyopadhyay, D. Urban sprawl measurement from remote sensing data. Appl. Geogr. 30(4), 731-740 (2013).

[13] Bruno Taut, L.F. The City Crown (1919). http://socksstudio.com/2013/09/28/bruno-tautthe-city-crown-1919/. 
[14] Le Corbusier. Towards a New Architecture (1927). http://www.amazon.com/TowardsNew-Architecture-Le-Corbusier/dp/1614276056.

[15] Wright, F.L. The Disappearing City (New York: W.F. Payson, 1932).

[16] Arcosonti (Cosanti Foundation, 2012) https://arcosanti.org/visit_us.

[17] U.S. Green Building Council. LEED (2015). http://www.usgbc.org/leed.

[18] International Living Future Institute. Living Buildings Challenge (2015). http://livingfuture.org/lbc.

[19] Institute for Sustainable Infrastructure (2017). https://sustainableinfrastructure.org.

[20] U.S. Energy Information Administration. Assumptions to the Annual Energy Outlook 2016, Chapter 5, Table 5.2 (Washington, D.C., 2017)

https://www.eia.gov/outlooks/aeo/assumptions/pdf/commercial.pdf.

[21] Pacific Northwest National Laboratory \& U.S. Department of Energy. A Vision for Future Buildings (Richland, Washington, undated webpage). http://futurebuildings.labworks.org/.

[22] ASME J. Sol. Energy Eng. 139(1) (2017).

http://solarenergyengineering.asmedigitalcollection.asme.org/issue.aspx?journalid=132\&iss $\underline{\text { ueid }=935802 \& \text { direction }=\mathrm{P}}$.

[23] U.S. Census Bureau. Population Totals, National Totals: Vintage 2014 (Washington, D.C., 2015). http://www.census.gov/popest/data/national/totals/2014/index.html.

[24] Ortman, J.M., Velkoff, V.A., \& Hogan, H. An Aging Nation: The Older Population in the United States (Washington, D.C.: U.S. Census Bureau, 2014).

https://www.census.gov/prod/2014pubs/p25-1140.pdf.

[25] United Nations, Department of Economic and Social Affairs, Population Division. World Population to 2030 (New York, Publication no. ST/ESA/SER.A/236, 2004).

http://www.un.org/esa/population/publications/longrange2/WorldPop2300final.pdf.

[26] United Nations, Department of Economic and Social Affairs, Population Division. World Urbanization Prospects: The 2014 Revision, Highlights (New York, Publication no. ST/ESA/SER.A/352, 2014). http://esa.un.org/unpd/wup/Highlights/WUP2014Highlights.pdf.

[27] Benyu, J.M. Biomimicry: Innovation Inspired by Nature (Perennial, 2002). https://biomimicry.org/janine-benyus/\#.VwgX qulZ14.

[28] Rouse, D., \& Bunster-Ossa, I. Green Infrastructure: A Landscape Approach (Chicago: American Planning Association, PAS Report no. 571, 2013).

[29] Wilson, E.O. Biophilia (Harvard University Press, 1986). http://www.amazon.com/Biophilia-Edward-O-Wilson/dp/0674074424.

[30] Comarazamy, D.E., González, J.E., \& Luvall, J.C. Quantification and Mitigation of LongTerm Impacts of Urbanization and Climate Change in the Tropical Coastal City of San 
Juan, Puerto Rico. Int. J. Low-Carbon Tech., Special Issue on Mitigation Alternatives (2013). doi: 10.1093/ijlct/ctt059.

[31] Chapin, T., et al. Envisioning Florida's Future: Transportation and Land Use in an Automated Vehicle World (Tallahassee: Florida Department of Transportation, Report No. 035048, 2016).

[32] Park, J. Are Humans Good Sensors? Using Occupant as Sensors for Indoor Environmental Quality and Thresholds that Matter (Pittsburgh: Carnegie Mellon University, School of Architecture, $\mathrm{PhD}$ thesis, 2015).

[33] Yun, R., Scupelli, P., Aziz, A., \& Loftness, V. Sustainability in the workplace: nine intervention techniques for behavior change. Persuasive Technology (New York: Springer, pp. 253-265).

[34] Peters, S., Loftness, V., \& Hartkopf, V. The intuitive control of smart home and office environments. Proceedings of the 10th SIGPLAN Symposium on New Ideas, New Paradigms, and Reflections on Programming and Software, Portland, Oregon (2011).

[35] Rockström, J. et al. A safe operating space for humanity. Nature 461, 472-475 (2009). http://www.nature.com/nature/journal/v461/n7263/full/461472a.html.

[36] Simpson, E.H. Measurement of diversity. Nature 163, 688 (1949).

[37] Shannon, C.E., \& Wiener, W. The Mathematical Theory of Communication (Urbana: University of Illinois Press, p.177, 1949).

[38] Hill, M.O. Diversity and Evenness: A Unifying Notation and Its Consequences. Ecology 54(2), 427-432 (1973).

[39] Kulhavy, D., Unger, D., Hung I.-K., Wu, D., \& Sun, J. Comparison of Tree Condition and Value for City Parks and Stephen F. Austin State University in Nacogdoches, Texas, U.S (Nacogdoches, Texas: Stephen F. Austin State University, Faculty Publications, Paper no. 220, 2014). http://scholarworks.sfasu.edu/forestry/220.

[40] International Living Future Institute. Living Buildings Challenge (2014). https://livingfuture.org/lbc/

[41] U.S. Geological Survey. Estimated Use of Water in the United States in 2010. (Reston, Virginia, Circular 1405, 2014). http://pubs.usgs.gov/circ/1405/pdf/circ1405.pdf.

[42] U.S. Energy Information Administration. Frequently Asked Questions: How many smart meters are installed in the United States, and who has them? (2016).

https://www.eia.gov/tools/faqs/faq.php?id=108\&t=3.

[43] Edison Foundation. Utility-Scale Smart Meter Deployments: Building Block of the Evolving Power Grid (Washington, D.C., 2014). http://www.edisonfoundation.net/iei/Documents/IEI_SmartMeterUpdate_0914.pdf. 
[44] U.S. Energy Information Administration. 2003 CBECS Survey Data (Washington, D.C., undated webpage).

https://www.eia.gov/consumption/commercial/data/2003/index.cfm?view=consumption.

[45] U.S. Energy Information Administration. 2012 CBECS Survey Data (Washington, D.C., undated webpage). https://www.eia.gov/consumption/commercial/data/2012/

[46] U.S. Environmental Protection Agency. DRAFT Inventory of U.S. Greenhouse Gas Emissions and Sinks: 1990-2015, EPA 430-P-17-001, Draft for public review (Washington, D.C., 2017). https://www.epa.gov/sites/production/files/2017-

02/documents/2017 complete report.pdf.

[47] U.S. Department of Energy. A Common Definition for Zero Energy Buildings (Washington, D.C. 2015).

http://energy.gov/sites/prod/files/2015/09/f26/A\%20Common\%20Definition\%20for\%20Ze ro $\% 20$

[48] U.S. Energy Information Administration. Electric Power Monthly, Table 6.1.B. Net Summer Capacity for Estimated Distributed Solar Photovoltaic Capacity by Sector (Megawatts): 2014 - November 2016 (Washington, D.C., 2017). http://www.eia.gov/electricity/monthly/epm_table_grapher.cfm?t=epmt_6_01_b.

[49] U.S. Energy Information Administration. Annual Energy Outlook 2015 with Projections to 2040 (Washington, D.C. 2015). http://www.eia.gov/forecasts/aeo/pdf/0383(2015).pdf.

[50] National Fire Protection Association. NFPA 70: National Electrical Code (2017). http://www.nfpa.org/codes-and-standards/all-codes-and-standards/list-of-codes-andstandards? mode $=$ code $\&$ code $=70$

[51] Tucker, R.W., \& Grimm, S. Emergency power for fire, life safety systems. Consulting Specifying Engineer (2011). http://www.csemag.com/single-article/emergency-power-forfire-life-safety-systems/24aeb7ac12963c6551d913007dff4824.html.

[52] Archtoolbox. Emergency and Standby Power Systems for Buildings (undated webpage). https://www.archtoolbox.com/materials-systems/electrical/emergency-power-systems-forbuildings.html.

[53] Hernandez, G., \& Hagerman, J. Supporting a Thriving Transaction-Based Controls Ecosystem. 2016 ACEEE Summer Study on Energy Efficiency in Buildings, Pacifica Grove, CA (2016). http://aceee.org/files/proceedings/2016/data/papers/3 119.pdf.

[54] BRE Group, Inc. Occupierview (2015) https://assets.recenter.tamu.edu/Documents/MktResearch/US-Office-CBREOccupierView.pdf

[55] Redfin. How Walk Score Works (2016). https://www.redfin.com/how-walk-score-works.

[56] U.S. Environmental Protection Agency. U.S. transportation sector greenhouse gas emissions 1990-2013. (Washington, D.C., 2015). http://www3.epa.gov/otaq/climate/documents/420f15032.pdf. 
[57] World Resources Institute. The Greenhouse Gas Protocol (Washington, D.C., 2012). http://www.ghgprotocol.org/calculation-tools/faq.

[58] U.S. General Services Administration. GSA Carbon Footprint Tool (Washington, D.C., 2015). http://www.gsa.gov/portal/content/162265.

[59] Guckert, D., \& King, J. R. Designing for Stewardship: Aligning Project Decisions with the Total Cost of Ownership. Facilities Manager, November/December 2006, 28-31 (2006). http://www.facilities.uiowa.edu/infolibrary/DesigningforStewardship(APPANovDec06).pd f.

[60] Havliand, D. Life Cycle Cost Analysis 2 : Using It In Practice (Washington, D.C.: American Institute of Architects, 1969). http://www.amazon.com/Life-cycle-cost-analysispractice/dp/0913962074.

[61] Gardner, M. Total Cost of Ownership (McKinstry, 2013). http://www.buildersassociation.org/docs/Education/Estimating\%20Academy/Mark\%20Gar dner\%20Total\%20Cost\%20of\%20Ownership.pdf.

[62] BOMA International. The BOMA-Kingsley Report (Washington, D.C., 2015). http://www.boma.org/research/newsroom/boma-kingsley/Pages/default.aspx.

[63] Institute of Market Transformation. Building Rating (Washington, D.C., 2015). http://buildingrating.org.

[64] Institute of Market Transformation. U.S. Building Area Covered Annually (Washington, D.C., 2015). http://buildingrating.org/graphic/us-building-area-covered-annually.

[65] U.S. Energy Information Administration. 2012 CBECS Preliminary Results (Washington, D.C., 2015). http://www.eia.gov/consumption/commercial/reports/2012/preliminary/.

[66] Weinstein, M.C., \& Stason, W.B. Foundations of costeffectiveness analysis for health and medical practices. N. Engl. J. Med. 296, 716-721 (1977).

[67] World Bank. World Development Report, Investing in Health 1993 (New York: Published for the World Bank, Oxford University Press, 1993).

[68] Murray, C.J.L. Disability-adjusted life years (DALYs) for 291 diseases and injuries in 21 regions, 1990-2010: a systematic analysis for the Global Burden of Disease Study 2010. The Lancet 380(9859), 2197-2223 (2012). doi:http://dx.doi.org/10.1016/S01406736(12)61689-4.

[69] Institute of Medicine. Clear the Air: Asthma and Indoor Air Exposures (Washington, D.C.: National Academies Press, 2000). http://www.nap.edu/catalog/9610/clearing-the-airasthma-and-indoor-air-exposures.

[70] U.S. Department of Energy. Accelerate Energy Productivity 2030. A Strategic Roadmap for American Energy Innovation, Economic Growth, and Competitiveness (Washington, D.C., 2015). http://www.energy2030.org/roadmap. 
[71] U.S. Department of Commerce, Bureau of Economic Analysis. Industry Data: Value Added by Industry (Washington, D.C., 2016).

http://www.bea.gov/iTable/iTable.cfm?ReqID=51\&step=1\#reqid=51\&step=51\&isuri=1\&5 $\underline{114=\mathrm{a} \& 5102=1}$.

[72] U.S. Bureau of Labor Statistics. Economic News Release: Productivity Costs, First Quarter 2016, Preliminary. (Washington, D.C., 2016).

http://www.bls.gov/news.release/prod2.nr0.htm.

[73] Sprague, S. What can labor productivity tell us about the U.S. economy? Productivity 3(12) (2014). http://www.bls.gov/opub/btn/volume-3/what-can-labor-productivity-tell-us-aboutthe-us-economy.htm.

[74] Organisation for Economic Co-operation and Development. Gross domestic product (GDP) (indicator) (Paris, 2016). https://data.oecd.org/gdp/gross-domestic-productgdp.htm\#indicator-chart. doi: 10.1787/dc2f7aec-en.

[75] U.S. Department of Commerce, Bureau of Economic Analysis. Industry Data, GDP by industry. (Washington, D.C., undated webpage). http://www.bea.gov/iTable/index industry gdpIndy.cfm.

[76] U.S. Energy Information Administration. Annual Energy Outlook 2015 (Washington, D.C., 2015).

[77] U.S. Department of Energy, Office of Energy Efficiency and Renewable Energy. Buildings Energy Data Book: Notes on Embodied Energy (Washington, D.C., 2016). http://buildingsdatabook.eren.doe.gov/TableView.aspx?table=Notes.

[78] Biswas, W.K. Carbon footprint and embodied energy consumption assessment of building construction works in Western Australia. Intern. J. Sustain. Built Environ. 3(2), 79-186 (2014). doi:10.1016/j.ijsbe.2014.11.004.

[79] Menzies, G.F. 2012. Embodied energy considerations for existing buildings. Historical Scotland Technical paper 13. http://www.historic-scotland.gov.uk/technicalpaper13.pdf

[80] Dixit, M.K. Fernandez-Solis, J.L., Lavy, S., \& Culp, C.H. Identification of parameters for embodied energy measurement: a literature review. Energy and Buildings 42(8), 1238-1247 (2010).

[81] Canadian Architect. Measures of Sustainability (Toronto, undated webpage) https://www.canadianarchitect.com/asf/perspectives_sustainibility/measures_of_sustainabli ty/measures of sustainablity embodied.htm.

[82] U.S. Department of Energy. DOE Quadrennial Technology Review, Ch 5 (Washington, D.C., 2015).

[83] U.S. Department of Energy, Office of Energy Efficiency and Renewable Energy. The National Opportunity for Interoperability and its Benefits for a Reliable, Robust, and Future Grid Realized through Buildings (Washington, D.C., 2016). https://energy.gov/sites/prod/files/2016/03/f30/Interoperability\%20and\%20National\%20Be nefits\%20Through\%20Buildings-031616.pdf 